\title{
25. Izglītība un darba tirgus
}

\author{
Zane Vārpiṇa, Ināra Kantāne
}

Svarīgs Latvijas tautsaimniecības attīstības priekšnosacījums ir darba tirgus prasībām atbilstošas kvalifikācijas darbaspēks, īpaši Latvijā, kur darbaspēks ir viens no svarīgākajiem ekonomikas resursiem. Vienlaicīgi individuālā līmenī izglìtība un darba tirgus statuss ir nesaraujami saistīti. Cēlonība starp indivīda izglìtību un viņa darba tirgus situāciju ir abpusēja - nodarbinātība ietekmē izglìtību un izglītība savukārt ietekmē nodarbinātîbas iespējas un ražìgumu (25.1. tabula).

25.1. tabula. Izglītības līmeṇa un darba tirgus savstarpējā ietekme

\begin{tabular}{|c|c|}
\hline \multicolumn{2}{|c|}{ Nodarbinātības ietekme uz izglītību } \\
\hline & $\begin{array}{l}\text { Dažāds efekts: } \\
\text { • Darba tirgus pieprasījums nosaka izglītības izvēli } \\
\text { • Sliktos darba tirgus apstākḷos iestāšanās darba tirgū nav pievilcīga, jaunieši } \\
\text { izvēlas studēt (drosmi zaudējuša darbinieka efekts), studijām ir mazas } \\
\text { alternatīvās izmaksas } \\
\text { • Tajā pašā laikā sliktos darba tirgus apstākḷos samazinās algas un } \\
\text { mājsaimniecību ienākumi sarūk, citiem mājsaimniecības locekḷiem var } \\
\text { rasties nepieciešamība strādāt, lai to kompensētu (papildu darbinieka } \\
\text { efekts), vai arī viṇi nevar aț̣auties samaksāt studiju maksu }\end{array}$ \\
\hline \multicolumn{2}{|c|}{ Augstāka izglītības līmeṇa ietekme uz nodarbinātību un ražīgumu } \\
\hline Nodarbinātība & $\begin{array}{l}\text { Vienmēr pozitīvs efekts: } \\
\text { - Mazāks risks tikt atlaistiem, lielāks firmai specifiskā cilvēkkapitāla } \\
\text { uzkrājums } \\
\text { - Nekvalificētu darbinieku aizstāšana ar kvalificētiem (izspiešanas efekts) } \\
\text { - Darbinieki ir elastīgāki darba tirgū, nepieciešamības gadījumā viṇiem vieglāk } \\
\text { atrast jaunu darbu }\end{array}$ \\
\hline Ražīgums & $\begin{array}{l}\text { Pozitīvs, netiešs, bieži nenozīmīgs efekts: } \\
\text { - Kopumā skolas apmeklēšana palielina prasmes, darba devēji maksā vairāk } \\
\text { par augstāku kvalifikāciju, sagaidot augstāku produktivitāti } \\
\text { - Skološanās var būt tikai signāls, ka indivīdam piemīt noteiktas prasmes } \\
\text { - Darba tirgus nereti neatrodas līdzsvarā }\end{array}$ \\
\hline
\end{tabular}

Avots: autoru izstrādāts, balstoties uz Cunska, 2012. 
Darba tirgus situācija ietekmē indivīdu lēmumus iegūt izglìtîbu, t. i., pieprasījumu pēc izglītības. Zinātniskajā literatūrā sastopami divi skaidrojumi. Pirmkārt, sliktā darba tirgus situācijā (augsts bezdarba, īpaši jauniešu bezdarba, līmenis) studijām ir mazas alternatīvās izmaksas, jo algas ir zemas un uz darbavietām ir liela konkurence. Lìdz ar to studijas ir labs laika ieguldījuma veids, kas palielina studējošo skaitu. Daudzos empīriskos pētījumos ir konstatēta šāda pozitīva sakarība starp kopējo bezdarbu un studējošo skaitu (Betts, McFarland, 1995; Card, Lemieux, 2000; Rice, 1987; Weber, 2002). Vienlaicīgi šādos pašos darba tirgus apstākḷ̆os var būt spēkā tieši pretējs - t. s. pievienotā darbinieka - efekts, kad, algām samazinoties, kāds no mājsaimniecības locekḷiem var zaudēt darbu un citiem tās locekḷiem var rasties nepieciešamība strādāt, lai to kompensētu, vai arì kad nevar aṭ̦auties samaksāt studiju maksu. Arī negatīva sakarība ir novērojama empīriskos pētījumos (Kane, 1995). Tātad kopumā jāsecina, ka darba tirgus situācija ir nozīmīgs faktors, kas nosaka pieprasījumu pēc izglìtības. Tieši darba tirgus, kurā tiek pieprasītas konkrētas prasmes, ilgtermiņā nosaka izglìtîbas saturu.

No otras puses, izglìtības lìmenis un joma nosaka indivīda nodarbinātību un karjeru. Zinātniskos pētijumos par bezdarba situāciju un tā ilgumu vienmēr konstatēta statistiski nozīmīga izglìtības ietekme (Nickell, 1979; Mincer, 1991; Hoynes, 1999), augstākas izglītības līmenis vienmēr tiek saistìts ar zemāku bezdarba risku. Tas tiek skaidrots divējādi: pirmkārt, varbūtību tikt atbrīvotam no darba samazina amata specifiska cilvēkkapitāla uzkrāšana, kas ir augstāka darbiniekiem ar augstāku izglìīibas līmeni un attiecīgi augstāku amatu, un, otrkārt, ar izspiešanas efektu (angl. crowding out) jeb pārizglìtību (overeducation), t. i., zemāk izglītotu darbinieku aizvietošanu ar labāk izglìtotiem vai pieredzējušākiem (Muysken, Ter Weel, 1999). Tehnolog̣iskā izaugsme attīstītās valstīs ir saistīta ar nepieciešamību pēc augstāk izglītota darbaspēka, kura prasmes ir elastīgākas un kurš vieglāk adaptējas jaunām prasībām un uztver jaunas zināšanas; zemāk izglìtotā darbaspēka veiktais manuālais darbs pirmām kārtām tiek aizvietots ar tehnoloǵijām, līdz ar to samazinot relatīvo pieprasijjumu pēc zemākas izglītîbas darbiniekiem. Tātad zemāk izglītoto cilvēku bezdarba risks ir augstāks, īpaši sliktā vai nestabilā darba tirgus situācijā (krīzē), kad, pieaugot bezdarbam, darba devēji var nopirkt vairāk prasmju par zemāku algu.

Izglìtības un produktivitātes saikne ir mazāk tieša. Lai gan pētījumi neparāda negatīvu sakarību starp izglītības līmeni un produktivitāti, arī statistiski nozīmīga pozitīva saikne netiek vienmēr pierādīta. Labi strādājoša tirgus apstākḷos darba devēji darbiniekiem maksā algu, kas vienāda ar to marginālo ražīgumu, tātad, ja darba devēji augstāk izglìtotiem darbiniekiem maksā augstāku algu, tiek uzskatīts, ka to produktivitāte ir augstāka. Tomēr darba tirgus bieži vien neatrodas līdzsvarā, piemēram, laika posmā starp 2005. un 2008. gadu Latvijā pieprasijjums pēc darbaspēka pārsniedza piedāvājumu, un šajā laikā alga neatspoguḷo ražìgumu. Otrkārt, izglìtību uzskata tikai par signālu, jo to 
iegūst tikai tādi indivīdi, kuru iedzimtās prasmes ir augstākas nekā citiem (Altonji, Pierret, 1996; Spence, 1974). Neskatoties uz diskusiju par reālo izglītības pienesumu indivīda produktivitātei, zinātniskajā literatūrā pastāv uzskats, ka izglîtības līmenis ir laba mērvienība (proxy) cilvēkkapitāla vērtībai. Vērtējot izglìtību darba tirḡ̄u, uzmanība jāpievērš trīs rādītājiem, kas raksturo problemātiku Latvijā.

Cilvēki ar augstāku izglītību vienmēr ir labāk nodarbināti. Latvijā iedzīvotājiem ar augstāku izglìtību nemainīgi visos pēdējos 20 gados darba iespējas ir bijušas lielākas. To atspoguḷo, piemēram, bezdarba rādītāji pa izglītības grupām (25.1. attēls). Lai arī bezdarba līmenis visām izglìtības grupām ir mainīgs, atspoguḷojot ekonomikas vispārējo situāciju un tās cikliskumu, iedzīvotājiem ar atškirīgiem izglìtības līmeņiem tas ir atšķirīgs, bet to dinamika ir diezgan lìdzìga.

Kopējais bezdarba līmenis Latvijā ir bijis mainīgs robežās no 6\% 2007. gadā straujā ekonomikas pieauguma periodā līdz nepilniem 20\% krīzes un pēckrīzes periodā 2010. gadā; līdzīga situācija bija arī 1996. gadā Krievijas krīzes iespaidā. Bezdarba līmenis iedzīvotājiem ar augstāko izglìtību 2010. gadā (25.1. attēls) bija tikai 10,7\%, turpretī iedzīvotājiem ar pamatizglìtību - 32,6\%, iedzīvotājiem ar vidējo izglìtību $23,8 \%$ un iedzivotājiem ar profesionālo izglītību - 19,2\%. Raksturīgi, ka visaugstākais bezdarba pieaugums krīzes laikā (2008-2010) skāra tos, kam ir pamatizglītība, bet bezdarba samazinājumu pēckrīzes periodā (2011. gadā salīdzinājumā ar 2010. gadu) visstraujāk izjuta cilvēki, kas ieguvuši augstāko izglìtîbu.

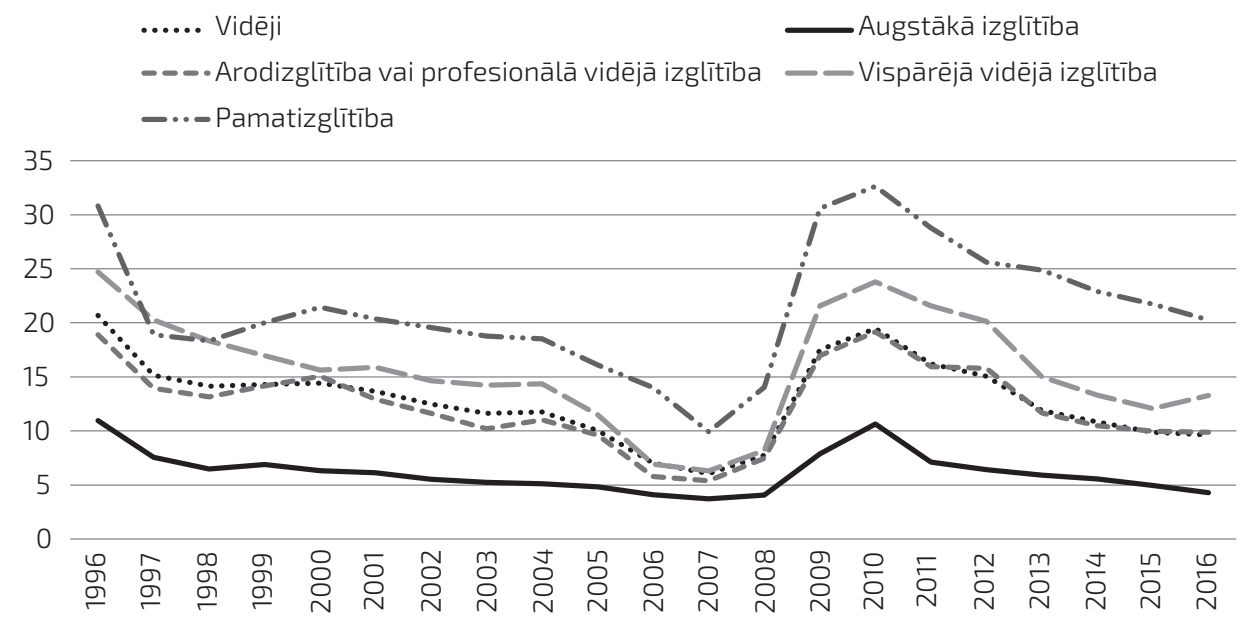

25.1. attēls. Bezdarbs sadalījumā pēc izglītības līmeṇa (1996-2016) procentos no visiem ekonomiski aktīvajiem iedzīvotājiem ar attiecīgo izglītību Avots: autoru veidots, izmantojot LR CSP datubāzes. 
Nepietiekama koordinācija starp darba tirgus vajadzībām un iegūto izglîtību. Pētijumā "Nākotnē stratēgisiski pieprasîtākās prasmes Latvijā" norādīts, ka viena no būtiskākajām darba tirgus problēmām ir "darbaspēka pieprasījuma un piedāvājuma nesabalansētība (prasmju un izglìtības neatbilstība)" (Kasalis u. c., 2012). Ekonomikas ministrijas informatīvajā ziņojumā par darba tirgus vidēja termiņa un ilgtermiņa prognozēm konstatēts, ka atsevišķās profesijās pat tad, ja atalgojuma līmenis ir relatīvi augsts, ir grūti apmierināt pieaugošo pieprasijjumu pēc atbilstošas kvalifikācijas darbaspēka (piemēram, IT nozarē pieprasījumu pēc programmētājiem), bet vienlaikus ir jomas, kur pastāv būtisks darbaspēka pārpalikums (dažādu pakalpojumu jomu pārvaldes (administrācijas) darbinieki, juridisko, sociālo un kultūras lietu speciālisti, tirdzniecības ağenti). Saskaṇā ar Ekonomikas ministrijas vidēja termiņa un ilgtermiņa darba tirgus prognozēm, saglabājoties pašreizējai darbaspēka sagatavošanas struktūrai, varētu būt šādas būtiskākās darba tirgus disproporcijas:

- neatbilstība starp augstākās izglìtības piedāvājumu un darba tirgus pieprasījumu;

- tāda darbaspēka trūkums, kam ir vidējā profesionālā izglìtība;

- liels to jauniešu īpatsvars, kuri nonāk darba tirgū bez konkrētas specialitātes un prasmēm;

- liels mazkvalificētā darbaspēka īpatsvars.

Tomēr Latvijā liela daḷa jauniešu izvēlas studēt sociālās zinātnes, komerczinības un tiesības - specialitātes, kurās nākotnē tiek prognozēts darbaspēka pārpalikums. 2016. gadā šajā izglītības tematiskajā grupā tika uzṇemti 34,7\% no visiem augstskolās un koledžās uzṇemtajiem jauniešiem, bet grādu vai kvalifikāciju ieguva 39,2\% no visiem augstskolu un koledžu absolventiem. Savukārt dabaszinātṇu, matemātikas un informācijas tehnolog̣iju izglītîbas tematiskajā grupā, kur jau pašreiz netiek pilnībā apmierināts darbaspēka pieprasījums, 2016. gadā tika uzṇemti tikai 9,7\% jauniešu; grādu vai kvalifikāciju šajās jomās ieguva $7,3 \%$ absolventu.

Augstskolas un augstākās izglītības koledžas Latvijā katru gadu absolvē aptuveni 2 reizes vairāk studentu nekā vidējās profesionālās izglîtības iestādes (finanšu krīzes laikā pat aptuveni 3 reizes vairāk). To daḷeji izskaidro nodarbinātības iespējas - tiem, kam ir augstāka izglìtîba, nodarbinātîbas iespējas vienmēr ir bijušas labākas. Tomēr satraucoši liela ir to jauniešu daļa, kuri neturpina mācības. 2016. gadā bija 31,4\% vidusskolu beigušo un 4,2\% pamatskolu beigušo jauniešu, kuri mācības neturpināja. Statistikas dati liecina, ka ekonomiski aktīvo iedzīvotāju vidū gadu no gada pieaug tādu nodarbināto īpatsvars un samazinās bezdarbnieku ippatsvars, kuriem ir augstākais izglìtības līmenis. 2018. gadā augstāko izglītību ieguvušo bezdarbnieku ìpatsvars veidoja 17,7\%, arodizglìtību vai profesionālo vidējo izglìtību ieguvušo bezdarbnieku ippatsvars - 31,5\%, bet to bezdarbnieku īpatsvars, kuriem ir vispārējā vidējā izglìtība, - 32,5\% (CSP, 2019). 


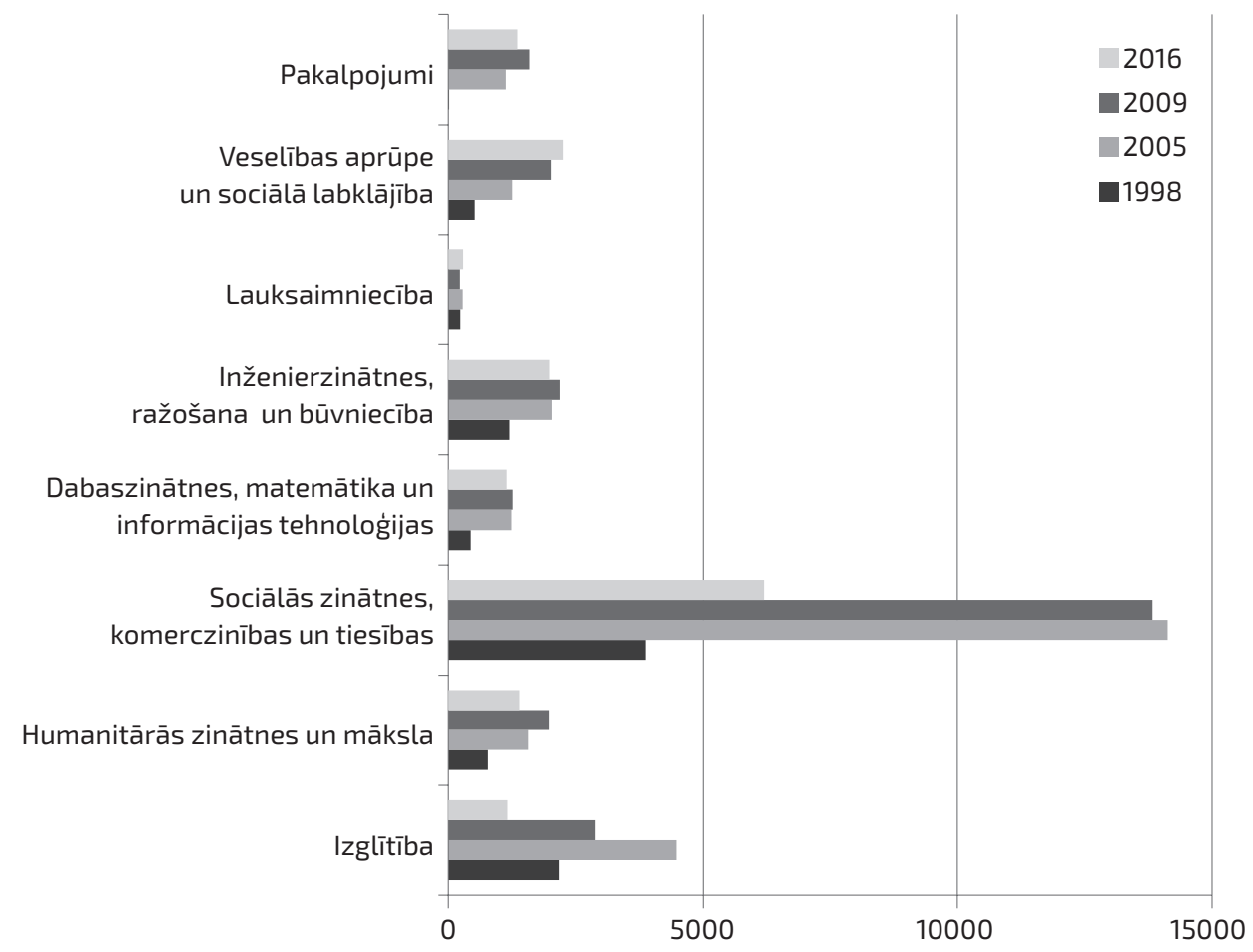

25.2. attēls. Grādu vai kvalifikāciju ieguvušo studentu skaits pa izglītības tematiskajām grupām augstskolās un koledžās (1998-2016)

Avots: autoru veidots, izmantojot LR CSP datubāzes.

Lai arī bezdarba rādītāji liecina par labu augstāka izglìtības līmen̦a iegūšanai, kas arī samazina bezdarba risku, ir nepieciešams padziḷnāti skatīt izglītības sadalījumu pa studiju jomām. Vidēja termiṇa un ilgtermiņa darba tirgus prognozes liecina par lielāku nepieciešamību pēc absolventu profesionālās izglìtības, kā arī pēc izglīiības zinātnes, tehnologiiju, inženierzinātṇu un matemātikas jomā (pēc t. s. STEM - Science, Technologu, Engineering, Mathematics - specialitātes), tomēr faktiski lielākais ir tieši sociālo zinātṇu programmu absolventu skaits. 25.2. attēls atspogulo izmaiņas absolventu sadalījumā pa zinātṇu nozarēm pēdējo 18 gadu laikā.

Kā redzams, visizteiktākās pārmaiņas skārušas tieši sociālo zinātņu jomu (sociālās zinātnes, komerczinības un tiesības), šo programmu absolventu skaits ir samazinājies no 14 tūkst. 2005. un 2009. gadā līdz mazliet vairāk nekā 6 tūkst. 2016. gadā. Tomēr tieši minētajā izglīiības tematiskajā grupā iepriekš bija visstraujākais pieaugums. Kaut arī absolūtos skaiț̣os sociālo zinātṇu programmu absolventu skaits ir samazinājies uz pusi, šĩ joma joprojām veido gandrīz 40\% no visiem absolventiem 2016. gadā. 
Lìdz ar kopējo studentu skaita samazināšanās tendenci arī absolventu skaits dabaszinātṇu, matemātikas un tehnologiiju studiju jomā ir nedaudz samazinājies: no 1265 cilvēkiem 2009. gadā līdz 1146 absolventiem 2016. gadā. Inženierzinātnēs, ražošanā un būvniecībā absolventu skaits saruka par apmēram 100 cilvēkiem. Varētu apgalvot, ka izglīiības jomas un veselības aprūpes un sociālās labklājības jomas dinamika attīstās saskaṇā ar ekonomikas vajadzībām studējošo un absolventu skaits izglìīibas sektorā krasi samazinās, bet palielinās veselības aprūpes un sociālās labklājības jomā. Šādu attīstību nosaka demogrāfiskās izmaiñas - sabiedrības novecošana, līdz ar to izglìtības sektors samazinās un turpinās samazināties, savukārt palielināsies nepieciešamība pēc veselības aprūpes un sociālās aprūpes.

Zema pieaugušo dalība formālā un neformālā izglītībā. Mūžizglītîba atspoguḷo darbaspēka aktivitāti izglìtošanas jomā un ir būtiska mūsdienu darba tirgus nepieciešamība. Ekonomiskai situācijai strauji mainoties, darbaspēkam nepieciešams elastīgi pielāgoties šìm izmaiņām. Pastāv uzskats, ka mūsdienās katram cilvēkam dzīves laikā nepieciešams pārmācīties vismaz trīs reizes. Saskaņā ar darbaspēka apsekojumu 2017. gadā Latvijā tikai 13\% visu darbspējīgo iedzīvotāju piedalās izglīitībā un apmācībā (25.3. attēls). Šis rādītājs krasi atpaliek ne tikai no Ziemel̦valstīm, kur iedzīvotāju dalība izglìtībā dzīves garumā pārsniedz 30\% (Dānijā 37\%, Zviedrijā 34\%, Somijā 30\%), bet arī no Igaunijas (21\%), Lietuvas (14\%) un praktiski no visas Rietumeiropas. Latvijā sieviešu dalība mūžizglìtībā nedaudz pārsniedz vīriešu dalību (14\% un attiecīgi 11\%).

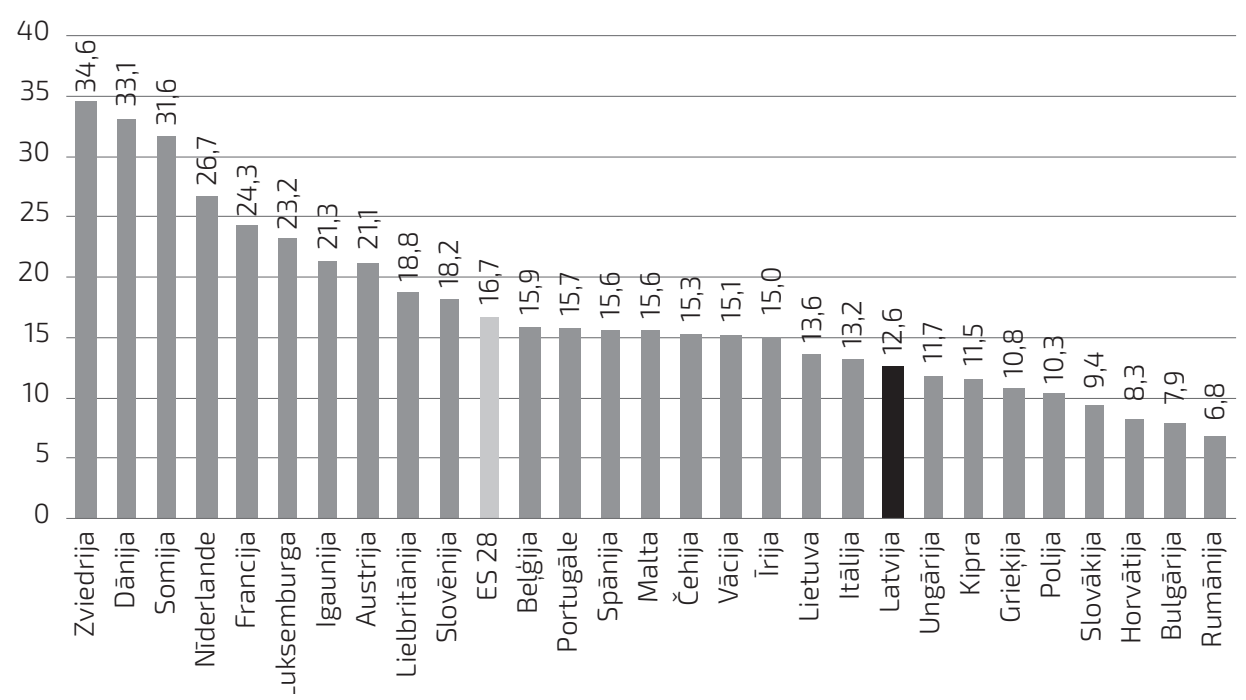

25.3. attēls. ES dalībvalstu darbspējas vecuma (18-65 gadi) iedzīvotāju dalība izglītībā un apmācībā (pēdējo 4 nedēelu laikā no aptaujas brīža) (2017)

Avots: autoru veidots, izmantojot Eurostat [trng_lfs_02]; darbaspēka apsekojuma dati. 
Turklāt iedzīvotāji ar augstāku sasniegto izglìtības līmeni arī turpmāk proporcionāli vairāk turpina mācīties, tādējādi vēl vairāk paplašinot izglìtības un kvalifikācijas atškirības.

Kopumā, vērtējot darbaspēka izglītîbu, jāsecina, ka darbaspēks Latvijā ir salīdzinoši augsti izglìtots, tomēr pastāv neatbilstība starp prasmju pieprasījumu un piedāvājumu pa zinātṇu jomām - novērojams darbinieku trūkums eksaktajās jeb t. s. STEM zinātņu jomās, savukārt sociālo zinātņu programmu absolventu skaits pārsniedz piedāvāto darbavietu skaitu. Iedzīvotāju mūžizglīiības rādītāji ir loti zemi.

\section{Literatūra un avoti}

Altonji, J., Pierret, C. (1996) Employer Learning and the Signalling Value of Education. NBER Working Paper, No. 5438. National Bureau of Economic Research, Cambridge, Mass.

Betts, J. R., McFarland, L. L. (1995) Safe Port in a Storm. The Impact of Labour Market Conditions on Community College Enrolment. The Journal of Human Resources, 30 (4): 741-765.

Card, D., Lemieux, T. (2000) Dropout and Enrolment Trends in the Post-War Period: What Went Wrong in the 1970s? NBER Working Paper, No. 7658. National Bureau of Economic Research, Cambridge, MA.

CSP (2019) Datubāze. Tabula NBG350 [http://data1.csb.gov.lv/pxweb/lv/sociala/sociala__nodarb__aktivitate__ikgad/NBG350.px/table/tableViewLayout2/?rxid=a39c3f49e95e-43e7-b4f0-dce111b48ba1 (23.02.2019.)].

Cunska, Z. (2012) Demogrāfisko un sociālo faktoru loma iedzīvotāju augstākās izglìtības lìmeña veidošanā un attīstībā Latvijā. Promocijas darbs. Rīga: Latvijas Universitāte.

Grādu vai kvalifikāciju ieguvušo studentu skaits pa izglītības tematiskajām grupām augstskolās un koledžās (2017) [https://www.csb.gov.lv/lv/statistika/statistikas-temas/socialie-procesi/izglitiba/tabulas/izg290/gradu-vai-kvalifikaciju-ieguvuso-studentuskaits (23.04.2017.)].

Hoynes, H. (1999) The Employment, Earnings, and Income of Less Skilled Workers Over the Business Cycle. NBER Working Paper, No. 7188, National Bureau of Economic Research, Cambridge, MA.

Iedzīvotāji pēc ekonomiskās aktivitātes statusa un izglītības līmeņa Latvijas reǵionos (2017) [https://www.csb.gov.lv/lv/statistika/statistikas-temas/socialie-procesi/nodarbinatiba/ tabulas/nbg351/iedzivotaji-pec-ekonomiskas-aktivitates (22.04.2017.)].

Informatīvais ziṇojums par darba tirgus vidēja un ilgtermiņa prognozēm (2016) [https://www. em.gov.lv/files/tautsaimniecibas_attistiba/dsp/EMZino_06_160616.pdf (20.12.2016.)].

Kane, T. J. (1995) Rising Public College Tuition and College Entry: How Well Do Public Subsidies Promote Access to College? NBER Working Paper, No. 5164. National Bureau of Economic Research, Cambridge, MA.

Kasalis, E., Brēḳis, E., Jēkabsone, S., Purmalis, K. (2013) Nākotnē stratēgiski pieprasìtākās prasmes Latvijā [https://www.em.gov.lv/files/tautsaimniecibas_attistiba/1_Petijums_nakotne_pieprasitakas_prasmes.pdf (20.12.2016.)].

Mincer, J. (1991) Education and Unemployment. NBER Working Paper, No. 3838. National Bureau of Economic Research, Cambridge, MA.

Muysken, J., Ter Weel, B. J. (1999) Overeducation, Job Competition and Unemployment. Working Paper, MERIT, Maastricht University, Maastricht. 
Nickell, S. (1979) Education and Lifetime Patterns of Unemployment. Journal of Political Economy, 87 (5): S117-S131.

Pamatskolu un vidusskolu beigušo turpmākā izglītība (2017) [https://www.csb.gov.lv/lv/statistika/statistikas-temas/socialie-procesi/izglitiba/tabulas/izg180/pamatskolu-un-vidusskolu-beiguso-turpmaka (23.04.2017.)].

Profesionālo izglītības iestāžu audzēkṇu sadalījums pēc vecuma un dzimuma (2017) [https://www.csb.gov.lv/lv/statistika/statistikas-temas/socialie-procesi/izglitiba/tabulas/izg221/profesionalo-izglitibas-iestazu-audzeknu (23.04.2017.)].

Rice, P. (1987) The Demand for Post-Compulsory Education in the UK and the Effects of Educational Maintenance Allowances. Economica, 54: 465-475.

Spence, M. (1974) Market Signalling. Harvard University Press, Cambridge.

Weber, B. A. (2002) The Link between Unemployment and Returns to Education: Evidence from 14 European Countries. Education + Training, 44 (4/5): 171-178. Doi $10.1108 / 00400910210432059$. 